ISSN: 2302-8556

E-Jurnal Akuntansi Universitas Udayana

Vol.27.1.April (2019): 362-387

DOI: https://doi.org/10.24843/EJA.2019.v27.i01.p14

\title{
Pengaruh Pengungkapan Corporate Social Responsibility pada Nilai Perusahaan Dengan Profitabilitas dan Leverage Sebagai Variabel Moderasi
}

\author{
I Wayan Rady Darmastika ${ }^{1}$ \\ Ni Made Dwi Ratnadi ${ }^{2}$ \\ ${ }^{1,2}$ Fakultas Ekonomi dan Bisnis Universitas Udayana (Unud), Bali, Indonesia \\ e-mail: radydarmastika@yahoo.com
}

\begin{abstract}
ABSTRAK
Penelitian ini bertujuan untuk mendapatkan bukti empiris pengaruh Pengungkapan Corporate Social Responsibility (CSR) pada Nilai Perusahaan dengan Profitabilitas dan Leverage sebagai variabel moderasi. Penelitian ini dilakukan pada perusahaan pertambangan yang terdaftar di Bursa Efek Indonesia (BEI) tahun 2013-2016. Jumlah sampel dalam penelitian ini adalah 41 perusahaan dengan 164 observasi karena terdapat 3 perusahaan pertambangan yang tidak memiliki informasi lengkap yang diperlukan dalam penelitian. Teknik analisis data yang digunakan adalah Moderated Regression Analysis (MRA). Berdasarkan hasil analisis penelitian ini ditemukan bahwa pengungkapan corporate social responsibility berpengaruh positif pada nilai perusahaan. Profitabilitas memperkuat pengaruh pengungkapan corporate social responsibility pada nilai perusahaan sedangkan leverage memperlemah pengaruh pengungkapan corporate social responsibility pada nilai perusahaan.
\end{abstract}

Kata kunci: Nilai perusahaan, corporate social responsibility

\section{ABSTRACT}

This study aims to obtain empirical evidence of the influence of Disclosure of Corporate Social Responsibility (CSR) on Corporate Value with Profitability and Leverage as a moderating variable. This research was conducted on mining companies listed on the Indonesia Stock Exchange (IDX) in 2013-2016. The number of samples in this study was 41 companies with 164 observations because there were 3 mining companies that did not have complete information needed in the study. The data analysis technique used is Moderated Regression Analysis (MRA). Based on the results of the analysis of this study it was found that the disclosure of corporate social responsibility has a positive effect on the value of the company. Profitability strengthens the influence of corporate social responsibility disclosure on company value while leverage weakens the influence of corporate social responsibility disclosure on company value.

Keywords: Company value, corporate social responsibility

\section{PENDAHULUAN}

Dalam suatu perusahaan kegiatan bisnis menjadi perilaku utama dari para pelaku bisnis. Selama ini perusahaan dianggap sebagai lembaga yang memberikan 
keuntungan bagi masyarakat, dimana menurut pendekatan akuntansi tradisional, perusahaan harus dapat memaksimalkan labanya agar dapat memberikan sumbangan yang maksimum kepada masyarakat. Namun, kegiatan bisnis tersebut tetap berorientasi pada keuntungan tanpa dibatasi oleh perbedaan sistem hukum. Kegiatan bisnis tersebut terutama yang bergerak di bidang pemanfaatan sumber daya alam baik secara langsung maupun yang tidak langsung tentu memberikan dampak pada lingkungan sekitarnya seperti masalah-masalah polusi dan limbah yang sangat merugikan masyarakat. Adanya dampak pada lingkungan tersebut mempengaruhi kesadaran masyarakat akan pentingnya melaksanakan tanggung jawab sosial atau yang dikenal dengan CSR (Corporate Social Responsibility), sebuah konsep yang tengah berkembang pesat dalam dunia industri (Stacia \& Juniarti, 2015).

Praktik pertambangan menjadi salah satu praktik yang berdampak sangat negatif terhadap lingkungan. Limbah dari hasil pertambangan yang dibuang ke laut menjadi masalah utama dari sektor pertambangan, hal tersebut selain dapat merusak ekosistem di laut, juga dapat merugikan masyarakat disekitarnya, contohnya pencemaran lingkungan di Teluk Buyat karena aktivitas pertambangan oleh PT Newmont Minahasa Raya (PT NMR). Teluk Buyat dijadikan sebagai lokasi pembuangan limbah tailing (limbah pertambangan) tambang PT NMR yang mengakibatkan ekosistem perairan laut di Teluk Buyat rusak parah akibat buangan tailing setiap harinya (Dinda, dkk, 2013).

Pengungkapan tanggungjawab sosial perusahaan yang sering juga disebut sebagai corporate social responsibility merupakan komitmen berkelanjutan dari 
ISSN: 2302-8556

E-Jurnal Akuntansi Universitas Udayana

Vol.27.1.April (2019): 362-387

bisnis untuk berperilaku etis dan berkontribusi terhadap pembangunan ekonomi sekaligus meningkatkan kualitas angkatan kerja dan masyarakat setempat secara luas (Georgeta dan Florinita, 2013). Menurut UU Perseroan Terbatas No. 40 Tahun 2007 pasal 74 yang menyatakan bahwa perseroan yang menjalankan kegiatan usahanya di bidang atau yang berkaitan dengan sumber daya alam wajib melaksanakan tanggung jawab sosial dan lingkungan. Di dalam berdirinya suatu perusahaan hal yang sangat penting untuk diperoleh adalah laba atau profit. Tanpa diperolehnya laba, perusahaan tidak dapat memenuhi tujuan lainnya yaitu pertumbuhan terus-menerus dan tanggung jawab sosial (corporate social responsibility).

Dalam teori signaling dijelaskan bahwa kegiatan sosial dan lingkungan memberikan informasi kepada investor tentang prospek return masa depan substansial. Pengungkapan CSR yang tepat dan sesuai harapan stakeholder akan memberikan sinyal berupa goodnews yang diberikan oleh manajemen kepada publik bahwa perusahaan memiliki prospek yang bagus di masa depan dan akan meningkatnya nilai perusahaan (Suwisnaya, 2017).

Kelangsungan hidup perusahaan dipengaruhi oleh banyak hal antara lain profitabilitas perusahaan itu sendiri. Profitabilitas digunakan sebagai variabel moderasi dalam penelitian ini karena profitabilitas merupakan salah satu alat ukur perusahaan untuk menentukan keefektifan kinerja perusahaan. Profitabilitas memiliki peran penting didalam perusahaan karena melalui profitabilitas yang tinggi dimiliki perusahaan, maka perusahaan tersebut akan mampu membayar segala kewajiban - 
kewajiban yang dimiliki oleh perusahaan sehingga perusahaan tetap dalam keadaan perusahaan yang likuid (Hanum, 2012). Menurut Sastrawan (2016) profitabilitas dianggap penting karena profitabilitas sebagai indikator dalam mengukur kinerja keuangan suatu perusahaan sehingga dapat dijadikan acuan untuk menilai perusahaan.

Faktor lain yang mempengaruhi Corporate Social Responsibility terhadap Nilai Perusahaan adalah leverage. Leverage mencerminkan seberapa besar perusahaan tergantung pada kreditur dalam membiayai aset perusahaan yang nantinya akan mempengaruhi tingkat kepercayaan investor didalam menanamkan sahamnya. Penggunaan leverage dapat menimbulkan beban dan risiko bagi perusahaan, apalagi jika keadaan perusahaan sedang memburuk. Di samping perusahaan harus membayar beban bunga yang semakin membesar, kemungkinan perusahaan mendapat penalti dari pihak ketiga pun bisa terjadi.

Nilai perusahaan merupakan persepsi investor terhadap tingkat keberhasilan perusahaan dalam mengelola sumber daya pada akhir tahun berjalan yang tercermin pada harga saham perusahaan. Semakin tinggi harga saham semakin tinggi pula nilai perusahaan, sebaliknya semakin rendah harga saham maka nilai perusahaan juga rendah atau kinerja perusahaan kurang baik. Menurut Kusumajaya (2001), nilai perusahaan merupakan nilai pasar dari suatu ekuitas perusahaan ditambah dengan nilai pasar hutang. Dengan demikan, penambahan dari jumlah ekuitas perusahaan dengan hutang perusahaan dapat mencerminkan nilai perusahaan. 
ISSN: 2302-8556

E-Jurnal Akuntansi Universitas Udayana

Vol.27.1.April (2019): 362-387

Perusahaan pertambangan dijadikan objek penelitian dikarenakan sektor ini berkaitan dengan kegiatan eksploitasi sumber daya alam yang rentan menimbulkan kerusakan lingkungan, sehingga $C S R$ yang diterapkan oleh perusahaan akan beragam dan banyak jumlahnya. Selain itu, perusahaan pertambangan juga lebih banyak menyajikan informasi pengungkapan kegiatan CSR dan besaran biaya yang dikeluarkan, khususnya untuk item-item yang berhubungan dengan ketenagakerjaan, komunitas sosial dan upaya-upaya perbaikan lingkungan. Dimana ketiga item yang lebih banyak diungkap oleh perusahaan pertambangan sesuai dengan kebutuhan penelitian yang dilakukan. Untuk itu peneliti lebih tertarik memilih perusahaan pertambangan sebagai sampel penelitian (Andreas et al., 2015).

Penelitian mengenai hubungan antara pengungkapan corporate social responsibility, profitabilitas, leverage, dan nilai perusahaan telah dilakukan oleh beberapa peneliti sebelumnya. Qomariah (2015) menyatakan bahwa pengungkapan corporate social responsibility berpengaruh positif dan signifikan terhadap nilai perusahaan. Putra (2015), Uadiale dan Fagbemi (2012), dan Vintila dan Duca (2013) menyatakan bahwa pengungkapan corporate social responsibility berpengaruh positif dan signifikan terhadap profitabilitas. Pratama dan Wiksuana (2016) menyatakan bahwa leverage berpengaruh positif terhadap nilai perusahaan. Saridewi, dkk (2016) menyatakan bahwa profitabilitas berpengaruh positif dan signifikan terhadap nilai perusahaan.

Roida (2008) dalam Danu (2011) menyatakan bahwa informasi yang 
disampaikan oleh pasar atau yang diterima oleh pasar merupakan sebuah sinyal yang dapat bermakna positif atau negatif, tergantung preferensi atas sinyal tersebut. Informasi jika dilihat dalam konteks sinyal dapat meningkatkan reputasi perusahaan, sehingga sinyal merupakan biaya untuk meningkatkan return (tingkat keuntungan) yang diharapkan oleh perusahaan. Salah satu corporate action yang merupakan informasi sekaligus tanda (signal) adalah perusahaan yang mengumumkan aktivitas CSR yang dilakukan oleh perusahaan yang bersnagkutan.

. Lujun (2010) dalam penelitiannya berpendapat bahwa selama beberapa tahun terakhir, informasi CSR mendapatkan perhatian lebih banyak dibandingkan informasi perusahaan yang lain dari stakeholder. Menurut Heal dan Garret (2004) dalam Danu (2011) menunjukkan bahwa aktivitas CSR dapat menjadi elemen yang menguntungkan sebagai strategi perusahaan dan memelihara hubungan yang dapat memberikan keuntungan jangka panjang perusahaan, sehingga berdasarkan stakeholder theory terdapat pengaruh CSR pada nilai perusahaan.

Daniati dan Suhairi (2006) dalam Sabrin dkk (2016) berpendapat bahwa salah satu ukuran yang menunjukkan nilai perusahaan adalah ukuran asset perusahaan. Perusahaan itu memiliki total aset menunjukkan bahwa perusahaan telah mencapai tahap kedewasaan dimana pada tahap ini arus kas perusahaan telah positif dan dianggap memiliki prospek bagus dalam waktu yang relatif lama, tapi juga mencerminkan bahwa perusahaan relatif lebih stabil dan lebih mampu menghasilkan keuntungan dibanding perusahaan dengan total asetnya kecil. Rubinhot dkk (2013) menyatakan bahwa nilai perusahaan merupakan sebuah nilai yang dapat digunakan 
ISSN: 2302-8556

E-Jurnal Akuntansi Universitas Udayana

Vol.27.1.April (2019): 362-387

untuk mengukur seberapa besar "Tingkat Kepentingan" sebuah perusahaan dilihat dari sudut pandang beberapa pihak seperti para investor yang mengaitkan nilai sebuah perusahaan dari harga sahamnya. Memaksimalkan nilai perusahaan sama dengan memaksimalkan harga saham dan itu juga yang diinginkan pemilik perusahaan karena nilai perusahaan yang tinggi mengindikasikan kemakmuran pemegang saham yang tinggi.

Tamba (2015) mendefinisikan corporate social responsibility sebagai komitmen perusahaan atau dunia bisnis untuk berkontribusi dalam pengembangan ekonomi yang berkelanjutan dengan memperhatikan tanggung jawab sosial perusahaan yang menitikberatkan pada keseimbangan antara perhatian terhadap aspek ekonomis, sosial dan lingkungan. Perusahaan yang ingin memiliki kelangsungan hidup haruslah memperhatikan "3P", yakni planet, people, dan profit (Bulan \& Astika, 2014). Seperti konsep triple bottom line dimana selain mengejar keuntungan (profit) suatu perusahaan juga memperhatikan kesejahteraan masyarakat (people) serta ikut berkontribusi aktif dalam menjaga kelestarian lingkungan (planet). Keberhasilan CSR ditentukan oleh dua faktor yaitu faktor internal dan faktor eksternal. Faktor internal yang mempengaruhi CSR yaitu pertimbangan ekonomi, budaya perusahaan, karyawan, dan pengaruh etika, sedangkan faktor eksternal yang mempengaruhi adalah persyaratan hukum dan pengaruh teknologi serta kebudayaan nasional (Ismail, 2009).

Pelaksanaan pengungkapan corporate social responsibility berperan penting 
dalam meningkatkan nilai perusahaan sebagai hasil dari peningkatan penjualan dan profitabilitas melalui loyalitas konsumen yang terbangun dengan cara pelaksanaan kegiatan sosial di lingkungannya (Putri \& Raharja, 2013). Teori sinyal (signaling theory) membahas mengenai dorongan perusahaan untuk mengungkapkan informasi ke pihak eksternal karena terjadi asimetri informasi antaramanajemen dengan pihak eksternal. Oleh sebab itu, semua informasi perusahaan, baik itu informasi keuangan maupun non keuangan harus diungkapkan oleh perusahaan. Salah satu informasi tersebut adalah tentang aktivitas CSR yang dilakukan perusahaan, yang diungkapkan dalam laporan tahunan perusahaan (Rosiana, dkk, 2013). Selain itu, berdasarkan teori sinyal (signalling theory) manajer yang memiliki informasi bagus tentang perusahaan berupaya menyampaikan informasi tersebut kepada investor luar agar saham perusahaan meningkat (Sugiarto, 2009). Stakeholder theory berpandangan bahwa perusahaan harus melakukan pengungkapan sosial sebagai salah satu tanggung jawab kepada para stakeholders (Wirakusuma, 2015).

Untuk dapat memenuhi aspek ekonomi dan non ekonomi diwujudkan dalam aktivitas $C S R$. Perusahaan yang melakukan investasi pada aktivitas $C S R$ akan memiliki resiko yang rendah karena potensi untuk dikenai biaya dimasa depan semakin kecil, disisi lain perusahaan juga akan mendapatkan reputasi yang bagus. Perusahaan juga berpeluang untuk dapat menaikkan penjualan sehingga perusahaan dapat memberikan return yang tinggi kepada investor. Hal ini akan memberikan respon yang positif dimata investor sehingga dapat menaikkan harga saham, jika harga saham naik maka nilai perusahaan dimata investor juga akan meningkat (Stacia 
ISSN: 2302-8556

E-Jurnal Akuntansi Universitas Udayana

Vol.27.1.April (2019): 362-387

\& Juniarti, 2015).

Hubungan antara pengungkapan corporate social responsibility dengan nilai perusahaan didukung oleh hasil penelitian yang dilakukan oleh dan Wirakusuma (2015) yang menyatakan bahwa terdapat hubungan positif dan signifikan antara pengungkapan corporate social responsibility dengan nilai perusahaan. Hal ini juga didukung oleh hasil penelitian yang dilakukan oleh Susanti, dkk (2012) yang juga menyatakan bahwa terdapat hubungan positif dan signifikan antara pengungkapan corporate social responsibility dengan nilai perusahaan. Artinya, semakin banyak aktivitas $C S R$ yang diungkapkan, maka semakin tinggi pula nilai suatu perusahaan.

$\mathrm{H}_{1}$ : pengungkapan corporate social responsibility berpengaruh positif pada nilai perusahaan.

Profitabilitas perusahaan merupakan kemampuan perusahaan dalam menghasilkan laba bersih dari aktivitas yang dilakukan pada periode akuntansi. Profitabilitas dapat menjadi pertimbangan penting bagi investor dalam keputusan investasinya, karena semakin besar dividen akan semakin menghemat biaya modal, disisi lain para manajer akan meningkatkan powernya bahkan bisa meningkatkan kepemilikannya akibat penerimaan dividen sebagai hasil keuntungan yang tinggi (Hesty, 2015).

Pelaksanaan pengungkapan tanggung jawab sosial perusahaan berkaitan erat dengan profitabilitas perusahaan. Hal ini dapat dilihat pada perusahaan-perusahaan yang menjalankan dan mengungkapkan aktivitas $C S R$. Perusahaan-perusahaan yang dapat menjalankan dan mengungkapkan aktivitas CSR dengan baik dapat 
meningkatkan reputasinya serta dapat mengurangi biaya atas kemungkinan tuntutan atau protes yang akan terjadi, sehingga profitabilitasperusahaan dapat meningkat (Darma dan Wirakusuma, 2015). Menurut Anggraini (2006) dalam Hesty (2015) semakin tinggi tingkat profitabilitas perusahaan maka semakin besar pengungkapan corporate social responsibility yang akan dapat meningkatkan nilai perusahaan, karena perusahaan dianggap akan menyisihkan dananya untuk melakukan pengungkapan tanggung jawab sosialnya lebih luas lagi. Begitu pula sebaliknya, semakin rendah tingkat profit suatu perusahaan, maka semakin rendah pula tingkat pengungkapan corporate social responsibility yang akan sedikit menurunkan nilai perusahaan, karena dananya akan digunakan untuk kebutuhan lain disbanding melakukan pengungkapan tanggung jawab sosial. Dapat disimpulkan bahwa profitabilitas akan memoderasi pengaruh pengungkapan Corporate Social Responsibility pada nilai perusahaan. Hal ini juga didukung oleh penelitian Susanti, dkk (2012) dan Rosiana, dkk (2013).

$\mathrm{H}_{2}$ : Profitabilitas memperkuat pengaruh pengungkapan corporate social responsibility pada nilai perusahaan.

Leverage digambarkan untuk melihat sejauh mana asset perusahaan dibiayai oleh hutang dibandingkan dengan modal sendiri. Leverage yang semakin besar menunjukkan risiko investasi yang semakin besar pula. Perusahaan dengan leverage yang rendah memiliki risiko leverage yang rendah pula (Mareta dkk, 2014).

Teori Keagenan memprediksi bahwa perusahaan dengan rasio leverage yang lebih tinggi akan mengungkapkan lebih banyak informasi, karena biaya keagenan 
ISSN: 2302-8556

E-Jurnal Akuntansi Universitas Udayana

Vol.27.1.April (2019): 362-387

perusahaan dengan struktur modal seperti itu lebih tinggi (Jensen \& Meckling, 1976) dalam Jayanti (2011). Perusahaan yang menggunakan hutang mempunyai kewajiban atas beban bunga dan beban pokok pinjaman. Penggunaan hutang memiliki risiko yang cukup besar atas tidak terbayarnya hutang, sehingga penggunaan hutang perlu memperhatikan kemampuan perusahaan dalam menghasilkan laba (Prasetyorini, 2013). Pengelolaan yang memiliki leverage cukup banyak cenderung menyusutkan penerapan CSR yang diciptakan untuk menghindari perhatian debtholders (Purba dan Yadnya, 2015).

Jadi, perusahaan dengan rasio leverage yang tinggi memiliki kewajiban untuk melakukan pengungkapan $C S R$ lebih luas daripada perusahaan dengan rasio leverage yang rendah. Hal ini didukung oleh hasil penelitian yang meyatakan adanya pengaruh secara tidak langsung antara pengungkapan corporate social responsibility pada nilai perusahaan dengan profitabilitas dan leverage sebagai pemoderasi (Susanti dkk, 2012).

$\mathrm{H}_{3}$ : Leverage memperlemah pengaruh pengungkapan Corporate Social Responsibility pada Nilai Perusahaan.

\section{METODE PENELITIAN}

Penelitian ini dilakukan pada perusahaan pertambangan yang terdaftar di Bursa Efek Indonesia (BEI) karena perusahaan yang terdaftar di BEI diwajibkan untuk mempublikasikan laporan keuangan dan laporan tahunan yang memuat informasi mengenai kinerja perusahaan baik itu dari segi keuangan dan non keuangan, sehingga 
objek yang diteliti dapat diamati. Periode penelitian dibatasi dari tahun 2013 sampai dengan 2016 dengan mengakses situs resmi dari Bursa Efek Indonesia (BEI).

Penggunaan Tobin's Q dalam menghitung nilai perusahaan juga dilakukan oleh peneliti-peneliti lainnya, seperti Dhama Putra dan Wirakusuma (2015) Rumus berikut ini digunakan untuk menghitung Tobin's Q (Ratnadewi, 2016). :

Tobin's $Q=\frac{M V E+D E B T}{T A}$

Keterangan:

MVE = closing price $\mathrm{x}$ jumlah saham yang beredar

DEBT $=$ Total Kewajiban

TA $=$ Total Aset

Untuk mengukur indeks $C S R$ adalah sebagai berikut :

$\operatorname{CSRIj}=\frac{\sum X i j}{\sum n j}$

Keterangan:

CSRI ${ }_{j}=$ Corporate Social Responsibility indeks perusahaan $\mathrm{j}$

$\sum \mathrm{X}_{\mathrm{ij}}=$ jumlah item yang diungkapkan oleh perusahaan $\mathrm{j}$,

$n_{j}=$ jumlah item untuk perusahaan $j, n_{j} \leq 91$.

$R O E$ sebagai salah satu ukuran profitabilitas menunjukkan kemampuan manajemen perusahaan dalam mengelola modal yang tersedia untuk menghasilkan laba setelah pajak yang nantinya berpengaruh terhadap pandangan investor (Wiagustini, 2010:81). ROE dapat dihitung dengan rumus sebagai berikut :

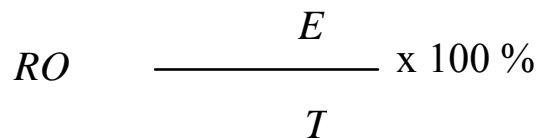

Keterangan :

ROE =Return of Equity 
ISSN: 2302-8556

E-Jurnal Akuntansi Universitas Udayana

Vol.27.1.April (2019): 362-387

$E A T=$ Earning after interest and $\operatorname{tax}$ (Laba bersih sesudah pajak)

$\mathrm{TE}=$ Total Ekuitas

Semakin tinggi tingkat leverage (rasio leverage/ekuitas) semakin besar kemungkinan akan melanggar perjanjian kredit sehingga perusahaan akan berusaha untuk melaporkan laba sekarang lebih tinggi (Giri Yanthi dan Budiasih, 2016). Variabel ini diukur dengan menggunakan rasio DER (debt to equity ratio) dengan cara membagi total utang terhadap modal perusahaan. Rumus perhitungannya adalah sebagai berikut:

$$
\mathrm{DER}=\frac{T U}{T E} X 100 \%
$$

Keterangan :

DER $=$ Debt to equity ratio

$\mathrm{TU}=$ Total Utang

$\mathrm{TE}=$ Total Ekuitas

Populasi dalam penelitian ini sebanyak 44 perusahaan pertambangan yang terdaftar di Bursa Efek Indonesia. Sampel dalam penelitian ini adalah perusahaan subsektor pertambangan yang terdaftar di BEI tahun 2013-2016, yang telah dipilih menggunakan metode non probability sampling dengan teknik sampel jenuh.

Metode penentuan sampel yang digunakan pada penelitian ini adalah metode non probability sampling dengan teknik sampling jenuh yaitu metode penarikan sampel bila semua anggota populasi dijadikan sebagai sampel. Dalam penelitian ini sampel yang akan diambil adalah seluruh perusahaan pertambangan yang terdaftar di BEI.

Metode pengumpulan data dalam penelitian ini adalah metode dokumentasi. Metode dokumentasi adalah pengumpulan data yang dilakukan dengan cara 
mengumpulkan dokumen-dokumen dan catatan-catatan yang didalamnya terdapat informasi yang diperlukan dalam penelitian. Teknik dokumentasi dalam penelitian ini dilakukan dengan cara pengumpulan, pencatatan dan pengcopyan data dalam laporan keuangan maupun laporan tahunan perusahaan pertambangan yang diperoleh dengan mengakses situs www.idx.co.id.

Analisis ini bertujuan untuk mengetahui pengaruh variabel moderating atas variabel independen dan variabel dependen apakah memperkuat atau memperlemah. Persamaan Moderated Regression Analysis adalah sebagai berikut:

$$
Y=\alpha+\beta_{1} X_{1}+\beta_{2} X_{2}+\beta_{3} X_{3}+\beta_{4} X_{1} X_{2}+\beta_{5} X_{1} X_{3}
$$

\section{Keterangan :}

$\mathrm{Y} \quad=$ Nilai Perusahaan

$\alpha \quad=$ Konstanta

$\beta_{1-} \beta_{5} \quad=$ Koefisien regresi

$\mathrm{X}_{1} \quad=$ Pengungkapan $C S R$

$\mathrm{X}_{2} \quad=$ Profitabilitas

$\mathrm{X}_{3} \quad=$ Leverage

$\mathrm{X}_{1} \mathrm{X}_{2} \quad=$ interaksi antara Pengungkapan $C S R$ dengan Profitabilitas

$\mathrm{X}_{1} \mathrm{X}_{3} \quad=$ interaksi antara Pengungkapan CSR dengan Leverage

\section{HASIL DAN PEMBAHASAN}

Penyajian statistik deskriptif bertujuan untuk memberi gambaran mengenai masingmasing variabel, yang menunjukkan jumlah sampel, nilai minimum, nilai maksimum, nilai rata-rata, dan deviasi standar masing-masing variabel. Deviasi standar menjelaskan seberapa jauh penyimpangan data dari nilai rata-ratanya (mean), sehingga dengan melihat deviasi standar dapat diketahui seberapa jauh rentangan atau range antara nilai minimum dengan nilai maksimum dari masing-masing variabel. 
ISSN: 2302-8556

E-Jurnal Akuntansi Universitas Udayana

Vol.27.1.April (2019): 362-387

Rentangan antara nilai minimum dengan nilai maksimum dikatakan tidak terlalu jauh atau relatif pendek apabila nilai deviasi standar tidak dua kali lebih besar dari nilai rata-ratanya. Hasil dari analisis statistik deskriptif penelitian dapat dilihat pada Tabel

1.

\section{Tabel 1.}

Hasil Analisis Statistik Deskriptif Variabel Penelitian

\begin{tabular}{llllll}
\hline Variabel & $\mathrm{N}$ & Min. & Maks. & $\begin{array}{l}\text { Rata- } \\
\text { rata }\end{array}$ & $\begin{array}{l}\text { Simpangan } \\
\text { Baku }\end{array}$ \\
\hline Pengungkapan $C S R\left(\mathrm{X}_{1}\right)$ & 164 & 0,08 & 0,86 & 0,37 & 0,19 \\
Profitabilitas $\left(\mathrm{X}_{2}\right)$ & 164 & $-161,89$ & 616,30 & 7,36 & 59,19 \\
Leverage $\left(\mathrm{X}_{3}\right)$ & 164 & $-2411,82$ & 2818,71 & 97,38 & 445,69 \\
& $\mathrm{~N}$ & Min. & Maks. & $\begin{array}{l}\text { Rata- } \\
\text { rata }\end{array}$ & $\begin{array}{l}\text { Simpangan } \\
\text { Baku }\end{array}$ \\
Nilai Perusahaan $(\mathrm{Y})$ & 164 & 0,17 & 3,14 & 0,88 & 0,51 \\
\hline
\end{tabular}

Sumber: Data diolah, 2018

Berdasarkan Tabel 1 menunjukkan statistik dari variabel dependen dan independen dalam penelitian ini. Beberapa penjelasan mengenai hasil perhitungan statistik diuraikan yaitu data pada variabel pengungkapan corporate social responsibility dengan nilai rata-rata sebesar 0,37 yang lebih besar dari simpangan baku sebesar 0,19 . Hal ini berarti data pada variabel pengungkapan corporate social responsibility memiliki fluktuasi nilai yang kecil. Nilai minimum untuk pengungkapan corporate social responsibility sebesar 0,08 sedangkan nilai maksimum sebesar 0,86 .

Data pada variabel profitabilitas dengan nilai rata-rata sebesar 7,36 yang lebih kecil dari simpangan baku sebesar 59,19. Hal ini berarti data pada variabel 
profitabilitas bersifat cenderung homogen. Nilai minimum untuk profitabilitas sebesar -161,89, sedangkan nilai maksimum sebesar 616,30.

Data pada variabel leverage dengan nilai rata-rata sebesar 97,38 yang lebih kecil dari simpangan sebesar 445,69. Hal ini berarti data pada variabel leverage bersifat cenderung homogen. Nilai minimum untuk leverage sebesar $-2411,82$ sedangkan nilai maksimum sebesar 2818,71.

Data pada variabel nilai perusahaan dengan nilai rata-rata sebesar 0,88 yang lebih besar dari simpangan sebesar 0,51. Hal ini berarti data pada variabel nilai perusahaan memiliki fluktuasi nilai yang kecil. Nilai minimum untuk nilai perusahaan sebesar 0,17, sedangkan nilai maksimum sebesar 3,14.

Adapun hasil dari pengujian Moderated Regression Analysis persamaan kedua pada penelitian ini disajikan pada Tabel 2 sebagai berikut:

\section{Tabel 2.}

Hasil Uji Moderated Regression Analysis (MRA)

\begin{tabular}{llllll}
\hline Model & \multicolumn{2}{l}{ Unstandardized } & \multicolumn{2}{l}{$\begin{array}{l}\text { Standardized } \\
\text { Coefficients }\end{array}$} \\
& $\mathrm{B}$ & Std. Error & Beta & $\mathrm{T}$ & Sig. \\
\hline (Constant) & -0.103 & 0.065 & & -1.580 & 0.116 \\
Pengungkapan CSR $\left(\mathrm{X}_{1}\right)$ & 0.177 & 0.072 & 0.198 & 2.462 & 0.015 \\
Profitabilitas $\left(\mathrm{X}_{2}\right)$ & 0.169 & 0.112 & 0.190 & 1.513 & 0.132 \\
Leverage $\left(\mathrm{X}_{3}\right)$ & 0.056 & 0.081 & 0.062 & 0.691 & 0.490 \\
Interaksi $\mathrm{X}_{1} \cdot \mathrm{X}_{2}$ & 0.162 & 0.077 & 0.220 & 2.100 & 0.037 \\
Interaksi $\mathrm{X}_{1} \cdot \mathrm{X}_{3}$ & -0.286 & 0.102 & -0.236 & -2.815 & 0.006 \\
Signifikansi F & 0,000 & & & & \\
R Square & 0,161 & & & & \\
Adjusted $\mathrm{R}$ Square & 0,135 & & & &
\end{tabular}

Berdasarkan hasil analisis regresi linier berganda seperti yang disajikan pada

Tabel 2 maka persamaan regresinya adalah sebagai berikut :

$$
Y=-0,103+0,177 X_{1}+0,169 X_{2}+0,056 X_{3}+0,162 X_{1} * X_{2}-0,286 X_{1} * X_{3}
$$


ISSN: 2302-8556

E-Jurnal Akuntansi Universitas Udayana

Vol.27.1.April (2019): 362-387

Berdasarkan persamaan regresi di atas dapat menjelaskan bahwa jika nilai koefisien variabel moderasi yaitu antara pengungkapan CSR dengan profitabilitas sama dengan nol maka peningkatan interaksi antara pengungkapan CSR dengan profitabilitas dapat meningkatkan nilai perusahaan sebesar 0,162 , sedangkan jika nilai koefisien variabel moderasi yaitu antara pengungkapan CSR dengan leverage sama dengan nol maka peningkatan interaksi antara peningkatan CSR dengan leverage dapat menurunkan nilai perusahaan sebesar 0,286.

Uji kesesuaian model regresi bertujuan untuk mengetahui apakah semua variabel bebas yang diidentifikasi (pengungkapan CSR, profitabilitas, leverage, variabel interaksi antara pengungkapan CSR dengan profitabilitas dan variabel interaksi antara pengungkapan CSR dengan leverage) tepat digunakan memprediksi nilai perusahaan. Uji ini sering juga disebut dengan uji F.

Hasil uji F (Ftest) menunjukkan bahwa nilai signifikansi P value 0,000 yang lebih kecil dari $\alpha=0,05$, ini berarti model yang digunakan pada penelitian ini adalah layak. Hasil ini memberikan makna bahwa seluruh variabel independen yaitu pengungkapan CSR, profitabilitas, leverage, variabel interaksi antara pengungkapan CSR dengan profitabilitas dan variabel interaksi antara pengungkapan CSR dengan leverage mampu memprediksi atau menjelaskan fenomena nilai perusahaan. Hal ini berarti model dapat digunakan untuk analisis lebih lanjut atau dengan kata lain model dapat digunakan untuk memproyeksikan karena hasil goodness of fitnya baik dengan nilai signifikansi $\mathrm{P}$ value 0,001 . 
Pengujian ini dilakukan untuk mengetahui pengaruh masing-masing variabel independen dan moderasi secara individual terhadap variabel dependen. Dari hasil analisis MRA, dapat dijelaskan sebagai berikut:

Hasil pengujian statistik yang dirangkum pada Tabel 2 menunjukkan bahwa koefisien regresi dari variabel pengungkapan CSR adalah 0,177 dan nilai signifikansinya adalah 0,015 yaitu lebih kecil dari $\alpha=0,05$ yang berarti pengungkapan CSR berpengaruh positif signifikan terhadap nilai perusahaan. Dengan demikian hipotesis yang diajukan dalam penelitian ini diterima.

Hasil pengujian statistik yang dirangkum pada Tabel 2 menunjukkan bahwa koefisien regresi dari variabel interaksi antara pengungkapan CSR dan profitabilitas adalah 0,162 dan signifikansinya 0,037 yaitu lebih kecil dari $\alpha=0,05$ yang berarti hipotesis diterima. Hal ini berarti profitabilitas memperkuat hubungan pengungkapan CSR pada nilai perusahaan. Dengan demikian hipotesis yang diajukan dalam penelitian ini diterima.

Hasil pengujian statistik yang dirangkum pada Tabel 2 menunjukkan bahwa koefisien regresi dari variabel interaksi antara pengungkapan CSR dan leverage adalah $-0,286$ dan signifikansinya 0,006 yaitu lebih kecil dari $\alpha=0,05$ yang berarti hipotesis diterima. Hal ini berarti leverage memperlemah hubungan pengungkapan CSR pada nilai perusahaan. Dengan demikian hipotesis yang diajukan dalam penelitian ini diterima.

Uji koefisien determinasi $\left(\mathrm{R}^{2}\right)$ digunakan untuk mengetahui dan mengukur kemampuan model dalam menerangkan variasi variabel independen. Peneliti 
ISSN: 2302-8556

E-Jurnal Akuntansi Universitas Udayana

Vol.27.1.April (2019): 362-387

menggunakan nilai adjusted $\mathrm{R}^{2}$ pada saat mengevaluasi yang mana model regresi terbaik, karena tidak seperti $\mathrm{R}^{2}$, nilai adjusted $\mathrm{R}^{2}$ (koefisien determinasi yang telah disesuaikan) dapat naik atau turun apabila satu variabel independen ditambahkan ke dalam model.

Hasil uji koefisien determinasi dalam Tabel 4.5 menunjukkan besarnya nilai adjusted $\mathrm{R}^{2}$ adalah sebesar 0,135. Ini berarti variasi nilai perusahaan dapat dipengaruhi secara signifikan oleh variabel pengungkapan CSR, profitabilitas, leverage, variabel interaksi antara CSR dengan profitabilitas dan variabel interaksi antara CSR dengan leverage sebesar 13,5 persen sedangkan sisanya sebesar 86,5 persen dijelaskan oleh faktor-faktor lain.

Hasil penelitian ini menunjukkan bahwa, pengungkapan $C S R$ berpengaruh positif pada nilai perusahaan. Oleh karena itu, hipotesis yang diajukan dalam penelitian ini diterima. Hipotesis tersebut diterima karena perusahaan yang melakukan CSR dianggap mampu memberikan kontribusi yang baik bagi masyarakat umum dan mampu bertanggungjawab atas aktivitas dan dampak yang ditimbulkan terhadap lingkungan sekitar. Hasil penelitian ini sesuai dengan Teori Sinyal yang menyatakan bahwa informasi yang dimuat dalam laporan tahunan perusahaan atau laporan sosial perusahaan diharapan dapat meningkatkan reputasi dan nilai perusahaan (Rustiarini, 2010).

Penelitian dengan hasil yang sama dilakukan oleh Susanti, dkk (2012), Fodio et al. (2013), Stacia \& Juniarti (2015), dan Wirakusuma (2015), Putri \& Raharja (2013) 
dan Ratnadewi (2016) yang menyatakan bahwa dengan adanya praktik CSR yang baik, diharapkan nilai perusahaan akan dinilai dengan baik oleh investor.

Hasil penelitian ini menunjukkan bahwa, profitabilitas mampu memoderasi dengan memperkuat pengaruh pengungkapan CSR pada nilai perusahaan. Oleh karena itu, hipotesis yang diajukan dalam penelitian ini yaitu profitabilitas memperkuat hubungan antara pengungkapan CSR pada nilai perusahaan diterima. Hipotesis tersebut diterima karena perusahaan yang mengungkapkan Corporate Social Responsibility dan didukung dengan tingkat profit yang tinggi maka dipercaya akan dapat meningkatkan nilai perusahaan, karena perusahaan dianggap akan menyisihkan dananya untuk melakukan pengungkapan tanggung jawab sosialnya lebih luas lagi. Begitu pula sebaliknya, perusahaan yang mengungkapkan Corporate Social Responsibility dengan tingkat profit yang rendah maka akan sedikit menurunkan nilai perusahaan, karena dananya akan digunakan untuk kebutuhan lain dibanding melakukan pengungkapan tanggung jawab sosial.

Hasil penelitian ini sesuai dengan teori sinyal memberikan isyarat bahwa peningkatan profitabilitas yang tercantum dalam laporan keuangan merupakan upaya memberikan sinyal positif kepada investor berkaitan dengan kinerja perusahaan dan pertumbuhan prospek usaha di masa mendatang (Rizqia, dkk., 2013). Menurut Anggraini (2006) dalam Hesty (2015) semakin tinggi tingkat profitabilitas perusahaan maka semakin besar pengungkapan corporate social responsibility yang akan dapat meningkatkan nilai perusahaan, karena perusahaan dianggap akan menyisihkan dananya untuk melakukan pengungkapan tanggung jawab sosialnya 
ISSN: 2302-8556

E-Jurnal Akuntansi Universitas Udayana

Vol.27.1.April (2019): 362-387

lebih luas lagi. Sehingga dapat disimpulkan bahwa, Pengungkapan Corporate Social Responsibility akan meningkatkan nilai perusahaan pada saat profitabilitas perusahaan meningkat. Hasil penelitian ini sejalan dengan penelitian Susanti, dkk (2012) yang mengindikasikan bahwa perusahaan yang memiliki tanggung jawab sosial terhadap lingkungan sekitarnya memberikan dampak positif, yang dalam jangka panjang akan tercermin pada keuntungan perusahaan (profit) dan peningkatan kinerja keuangan.

Hasil penelitian ini menunjukkan bahwa, leverage mampu memoderasi dengan memperlemah pengaruh pengungkapan CSR pada nilai perusahaan. Oleh karena itu, hipotesis yang diajukan dalam penelitian ini yatu leverage memperlemah hubungan antara pengungkapan CSR pada nilai perusahaan diterima. Hipotesis tersebut diterima karena semakin rendah tingkat rasio leverage suatu perusahaan, maka dipercaya semakin tinggi pengungkapan corporate social responsibility yang akan dilakukan perusahaan dan berpengaruh nantinya pada meningkatnya nilai perusahaan, karena dipercaya dana perusahaan akan tetap digunakan untuk melakukan pengungkapan tanggung jawab sosial perusahaan untuk menarik tingkat kepercayan investor yang diharapkan dapat menanamkan sahamnya, sedangkan semakin tinggi tingkat rasio leverage suatu perusahaan, maka semakin rendah pengungkapan corporate social responsibility yang dilakukan perusahaan dan berpengaruh terhadap penurunan nilai perusahaan, karena perusahaan dianggap akan mengurangi biaya yang dilakukan untuk melakukan pengungkapan tanggung jawab sosial dan menggunakan dana 
tersebut untuk membayar kewajiban-kewajiban perusahaan agar tidak menjadi sorotan dari para kreditur. Yuliana, dkk (2013) mengindikasikan bahwa variabel Leverage tidak memoderating pengaruh corporate social responsibility pada nilai perusahaan.

Penelitian yang dilakukan diharapkan dapat memberikan kontribusi mengenai pengaruh pengungkapan Corporate Social Responsibility pada nilai perusahaan dengan profitabilitas dan leverage sebagai variabel moderasi. Hasil uji dalam penelitian ini ditemukan bahwa pengungkapan Corporate Social Responsibility berpengaruh positif dan signifikan pada nilai perusahaan. Teori stakeholder mengatakan bahwa perusahaan bukanlah entitas yang hanya beroperasi untuk kepentingan sendiri namun harus memberikan manfaat bagi stakeholdernya. Tanggung jawab sosial perusahaan merupakan upaya perusahaan untuk memberikan kontribusi positif kepada stakeholder dengan meminimalisir efek negatif yang timbul dari segala kebijakan dan aktfitas operasional perusahaan. Profitabilitas mampu memoderasi (memperkuat) pengaruh pengungkapan CSR pada nilai perusahaan sedangkan leverage mampu memoderasi (memperlemah) pengaruh pengungkapan $C S R$ pada nilai perusahaan. Sejalan dengan teori signal yang mengungkapkan bahwa perusahaan harus mengungkapkan informasi yang dimiliki untuk mempengaruhi pengambilan keputusan investor. Semakin tinggi profitabilitas yang dimiliki perusahaan maka akan meningkatkan reputasi atau nilai perusahaan tersebut sedangkan semakin tinggi tingkat leverage suatu perusahaan maka akan menurunkan reputasi atau nilai perusahaan. 
ISSN: 2302-8556

E-Jurnal Akuntansi Universitas Udayana

Vol.27.1.April (2019): 362-387

Penelitian ini memberikan implikasi bagi investor sebagai pertimbangan dan pengetahuan mengenai nilai perusahaan serta faktor-faktor yang memengaruhinya. Investor dalam melakukan investasi atau penanaman modal di suatu perusahaan dapat melihat apakah perusahaan mengungkapkan corporate social responsibility, karena hal tersebut dianggap good news oleh investor sehingga mampu meningkatkan nilai perusahaan.

\section{SIMPULAN}

Berdasarkan pembahasan dapat disimpulkan bahwa Pengungkapan Corporate Social Responsibility berpengaruh positif pada Nilai Perusahaan. Hal ini berarti semakin tinggi tingkat pengungkapan CSR menyebabkan peningkatan nilai perusahaan. Profitabilitas memperkuat hubungan antara pengaruh pengungkapan Corporate Social Responsibility pada Nilai Perusahaan. Hal ini berarti perusahaan yang mengungkapkan corporate social responsibility dan didukung dengan tingkat profitabilitas yang tinggi akan menyebabkan peningkatan pada nilai perusahaan. Leverage memperlemah hubungan antara pengaruh pengungkapan Corporate Social Responsibility pada Nilai Perusahaan. Hal ini berarti perusahaan yang 
I Wayan Rady Darmastika dan Ni Made Dwi Ratnadi. Pengaruh ...

mengungkapkan corporate social responsibility dengan adanya leverage menyebabkan nilai perusahaan rendah.

Keterbatasan penelitian, hanya dilakukan pada perusahaan pertambangan, saran untuk peneliti agar memperluas penelitian dengan menguji pada sektor perusahaan yang berbeda, misalnya sektor manufaktur, sektor pertanian, sektor properti, sektor perdagangan. Saran bagi perushaan agar mengungkapkan corporate social responsibility secara berkesinambungan, untuk meningkatkan nilai perusahaan. 
ISSN: 2302-8556

E-Jurnal Akuntansi Universitas Udayana

Vol.27.1.April (2019): 362-387

\section{REFERENSI}

Andreas, H. H., Sucahyo, U. S., \& Elisabeth, D. (2015). Corporate Social Responsibility Dan Profitabilitas. Jurnal Manajemen, 15(1), 119-136.

Bulan, A. A. A. T., \& Astika, I. B. P. (2014). Moderasi Corporate Social Responsibility terhadap Pengaruh Kinerja Keuangan pada Nilai Perusahaan. EJournal Akuntansi Universitas Udayana, 8(2), 136-151.

Fodio, M. I., Abu-abdissamad, A. M., \& Oba, V. C. (2013). Corporate Social Responsibility and Firm Value in Quoted Nigerian Financial Services. International Journal of Finance and Accounting, 2(7), 331-340. https://doi.org/10.5923/j.ijfa.20130207.01

Georgeta \& Florinita. (2013). A Study of the Relasionship between Corporate Social responsibility - Financial Performance - Firm Size. The Bucharest University of Economic Studies, 62-67.

Gulton, R., Agustina \& Wijaya, S. W. (2013). Analisis Faktor-Faktor Yang Mempengaruhi Nilai Perusahaan Pada Perusahaan Farmasi Di Bursa Efek Indonesia. Jurnal Wira Ekonomi Mikroskil, 3(1), 51-60.

Hanum, Z. (2012). Pengaruh Profitabilitas Terhadap Modal Kerja Pada Perusahaan Makanan dan Minuman yang Terdaftar di Bursa Efek Indonesia. Jurnal Manajemen \& Bisnis, 11(2). Retrieved from http://www.dt.co.kr/contents.html?article_no=2012071302010531749001

Indrawan, D. C. (2011). Pengaruh Corporate Social Responsibility terhadap Kinerja Perusahaan. Skripsi Fakultas Ekonomi dan Bisnis Universitas Diponegoro.

Ismail, M. (2009). Corporate Social Responsibility And Its Role In Community Development: And International Perspective. The Journal of International Social Research, 2(9).

Kusumajaya, O. (2001). Pengaruh Struktur Modal dan Pertumbuhan Perusahaan terhadap Profitabilitas dan Nilai perusahaan pada Perusahaan Manufaktur di BEI. Tesis Program Studi Manajemen Program Pascasarjana Universitas Udayana.

Lestari, H. M. (2015). Pengaruh Corporate Social Responsibility Terhadap Nilai Perusahaan Dengan profitabilitas Sebagai Variabel Pemoderasi. Jurnal Ilmu \& Riset Akuntansi, 4(12), 1-19. 
Lujun. (2010). The Relations Among Evironmental Disclosure, Evironmental Performance and Financial Performance: An Empirical Study in China. Working Paper Series. Institute of Quantitative and Technical Economics.

Mareta, N.S., Siti, R.H., \& Sri, M.R. (2014). Pengaruh Leverage dan Profitabilitas terhadap Nilai Perusahaan. Jurnal Administrasi Bisnis, 8 (1), 1-10.

Purba, I.B.G.I.W. \& Yadnya, P. (2015). Pengaruh Ukuran Perusahaan dan Leverage terhadap Profitabilitas dan Pengungkapan Corporate Social Responsibility. EJurnal Manajemen Unud, 4(8), 2428-2443.

Putra, A.S. (2015). Pengaruh Corporate Social Responsibility Terhadap Profitabilitas. Jurnal Nominal, 4(2), 88-110.

Putri, H. C. M., \& Raharja, S. (2013). Pengaruh Corporate Social Responsibility terhadap Nilai Perusahaan dengan Kepemilikan Manajerial sebagai Variabel Moderating. Diponegoro Journal of Accounting, 2(3), 1-15. Retrieved from http://ejournal-s1.undip.ac.id/index.php/accounting.

Ratnadewi, P. A. (2016). Mekanisme Corporate Governance sebagai Variabel Pemoderasi Pengaruh Pengungkapan Corporate Social Responsibility pada Nilai Perusahaan. E-Jurnal Akuntansi Universitas Udayana, 14(1), 548-574.

Rifan, D. F., Andi, K., \& Widiyanthi, A. (2013). Pengaruh Corporate Social Responsibility dan Ukuran Perusahaan terhadap Kinerja Keuangan. Skripsi Fakultas Ekonomi dan Bisnis Universitas Diponegoro.

Rizqia, D. A., Aisjah, S., \& Sumiati. (2013). Effect of Managerial Ownership, Financial, Profitability, Firm Size, and Investment Opportunity on Dividend Policy and Firm Value. Research Journal of Finance and Accounting, 4(11), 120-130.

Rosiana, G.A.M.E., Juliarsa, G., \& Ratna Sari, M.M. (2013). Pengaruh Pengungkapan Corporate Social Responsibility Terhadap Nilai Perusahaan dengan Profitabilitas sebagai Variabel Pemoderasi. E-Jurnal Akuntansi Universitas Udayana, 5(3), 723-738.

Rustiarini, N. W. (2010). Pengaruh Corporate Governance dan Pengungkapan Corporate Social Responsibility terhadap Nilai Perusahaan (Studi Empiris Perusahaan yang Terdaftar di Bursa Efek Indonesia Periode 2007-2010). Jurnal Nominal, 1(1), 84-103. 
ISSN: 2302-8556

E-Jurnal Akuntansi Universitas Udayana

Vol.27.1.April (2019): 362-387

Sabrin, B. S., Dedy, T. S., \& Sujono. (2016). The Effect of Profitability on Firm Value in Manufacturing Company at Indonesia Stock Exchange. The International Journal Of Engineering And Science, 5(10), 81-89.

Saridewi, S.P., Susila, G.P.A.J., \& Yudiaatmaja, F. (2016). Pengaruh Profitabilitas dan Corporate Social Responsibility Terhadap Nilai Perusahaan. Jurnal Bisma Universitas Pendidikan Ganesha, 4, 1-9.

Sastrawan, I M. D. (2016). Pengaruh Langsung dan Tidak Langsung Good Corporate Governance terhadap Pengungkapan Tanggung Jawab Sosial Perusahaan. EJurnal Akuntansi Universitas Udayana, 14(11), 1-32.

Stacia, E., \& Juniarti. (2015). Pengaruh Pengungkapan Corporate Social Responsibility terhadap Nilai Perusahaan di Sektor Pertambangan. Jurnal Manajemen Keuangan, 3(2), 81-90.

Sugiarto. (2009). Hubungan antara Kepemilikan Manajerial, Return On Equity (ROE), Net Profil Margin (NPM), dan Tobin Q dengan Good Corporate Governance pada Perusahaan yang Terdaftar di Bursa Efek Indonesia. Tesis Program Studi Magister Manajemen Universitas Indonesia.

Suwisnaya, I P. P. (2017). Pengaruh Kebijakan Utang pada Nilai Perusahaan dengan Ukuran Perusahaan sebagai Variabel Moderasi. Skripsi Fakultas Ekonomi dan Bisnis Universitas Udayana.

Tamba, E. G. H. (2015). Pengaruh Struktur Kepemilikan Terhadap Pengungkapan Tanggung Jawab Sosial. Jurnal Akuntansi fakultas Ekonomi Universitas Negeri Padang, 3(1), 1-31.

Uadiale, O. M. \& Fagbemi, T. O. (2012). Corporate Social Responsibility and Financial Perfomance in Developing Economies: The Nigerian Experience. Journal of Economics and Sustainable Development, 3(4), 44-54.

Vintila, G. \& Duca, F. (2013). A Study of the Relationship between Corporate Responsibility - Financial Performance - Firm Size. Revista Romana de Statistica Trim, 1(1), 62-67.

Yuliana, K. \& Rheny. (2013). The Influence Of Corporate Social Responsibility To Firm Value With Profitability And Leverage As A Moderating Variable. Jurnal Ekonomi. Fakultas Ekonomi Universitas Riau, 21 (04), 1-34. 